\title{
Cytochrome $b$ yields new insight into taxonomic scope of Microtus schidlovskii (Rodentia, Arvicolinae, Microtus)
}

\author{
Tanya Zorenko*, Toni Koren \& Boris Kryštufek
}

\begin{abstract}
Microtus schidlovskii is a member of social voles (subgenus Sumeriomys) known from a small range in the highlands of Armenia. Similar voles were reported from Anatolia and Lebanon but were mainly ascribed to another enigmatic species $M$. irani. We assessed taxonomic position of $M$. schidlovskii from Armenia and its relationships with seven other species of social voles using molecular data. Phylogenetic reconstructions were based on a $409 \mathrm{bp}$ fragment of cytochrome $b \mathrm{M}$. schidlovskii and reference samples of $M$. irani, including $M$. irani karamani from Turkey and Lebanon. $M$. irani within its current scope emerged to be paraphyletic with respect to M. schidlovskii. Mean K2P distances in the iranischidlovskii-karamani cluster were the highest (0.038) between the irani and the schidlovskii lineages and the lowest (0.028) between the schidlovskii and the karamani lineages; the distance separating the irani and karamani lineages was intermediate (0.032). The irani-schidlovskii-karamani group is genetically more variable than any other species group of social voles. We conclude that voles from Lebanon and Turkey $(M$. irani karamani) are conspecific with $M$. schidlovskii from Armenia. Furthermore, genetic divergence between M. irani and M. schidlovskii is the lowest among the species of social voles. And finally, our study restricted geographic scope of $M$. irani to its type locality in Shiraz.
\end{abstract}

KEY WORDS: Microtus schidlovskii, phylogeny, taxonomy, cytochrome $b$.

Tanya Zorenko[zorenkot@lanet.lv], University of Latvia, RigaLV-1586, Krovald bulv. 4, Latvia; Toni Koren [toni.koren@zrs.upr.si], Science and Research Centre, University of Primorska, Koper, Slovenia; Boris Kryštufek [bkrystufek@pms-lj.si], Slovenian Museum of Natural History, Ljubljana, Slovenia.

\section{Цитохром $b$ приводит к новому пониманию таксономического статуса Microtus schidlovskii (Rodentia, Arvicolinae, Microtus)}

\author{
Т. Зоренко*, Т. Корен, Б. Криштуфек
}

\begin{abstract}
РЕЗЮМЕ. Полевка Шидловского Microtus schidlovskii Argyropulo, 1933, занимающая небольшой ареал в высокогорье Армении, является представителем общественных полевок подрода Sumeriomys. Близкие формы обнаружены в Анатолии и Ливане, однако, их обычно относят к мало изученному виду M. irani. С помощью молекулярного маркера оцениваются таксономические отношения $M$. schidlovskii из Армении и семи других видов общественных полевок. Филогенетические реконструкции основаны на фрагменте гена цитохрома $b$ (409 bp). M. schidlovskii образует сестринскую группу с М. irani, наиболее близка оказывается M. irani karamani из Турции и Ливана. M. irani является парафилетической группой по отношению к M. schidlovskii. Генетическая дистанция в кластере irani-schidlovskii-karamani наибольшая между irani и schidlovskii (0.038), наименьшая (0.028) между линиями schidlovskii и karamani; дистанция, разделяющая линии irani и karamani промежуточная (0.032). Группа irani-schidlovskii-karamani генетически более изменчива по сравнению с другими видами общественных полевок. Согласно полученным результатам, полевки из Ливана и Турции (M. irani karamani) конспецифичны M. schidlovskii из Армении. При этом генетическая дистанция между M. irani и M. schidlovskii наименьшая в группе общественных полевок. Наши исследования ограничивают ареал M. irani областью Шираза.
\end{abstract}

КЛЮЧЕВЫЕ СЛОВА: Microtus schidlovskii, филогения, таксономия, цитохром $b$.

\section{Introduction}

Social voles are one of the youngest, rapidly evolving and species-rich groups from a specious arvicoline genus Microtus Schrank, 1798. They are either classified in a subgenus Sumeriomys Argyropulo, 1933 (Argyropulo, 1933; Gromov \& Erbajeva, 1995; Abramson
\& Lissovsky, 2012; Zorenko, 2013), or as a socialis species groups within the subgenus Microtus (Jaarola et al., 2004). Social voles are a sister group to the arvalis species group (Martínková \& Moravec, 2012). Rapid speciation pulse in Sumeriomys, which was apparently triggered towards the end of the Middle Pleistocene, produced in rather short period more than 10 extant species (Kryštufek et al., 2010). 
The diploid chromosome numbers of social voles vary between 46 and 64 (Zima et al., 2013). In late 1980s Ayrumyan et al. (1986) convincingly demonstrated species independence of M. schidlovskii Argyropulo, 1933. Their results were corroborated subsequently by Akhverdyan et al. (1991a, b) and Golenishchev et al. (2002). M. schidlovskii is a cryptic species and differs from M. socialis Pallas, 1773 in lower diploid number of chromosomes.

First cross-breeding trials among various taxa of social voles date back into 1950s (Zakharyan, 1958). Crossing of $M$. schidlovskii $\times$ M. socialis binominatus Ellermann, 1941 produced in the first generation sterile hybrid males and fertile hybrid females (Orlov, 1971). These results were corroborated in subsequent studies (Akhverdyan et al., 1991; Makaryan et al., 1991; Zorenko et al., 1997).

Recently social voles with diploid number of chromosomes $2 n=60$ were found in two localities in eastern Anatolia (Yiðit et al., 2006). Another population of $2 \mathrm{n}=60$ social voles from Balkusan (Taurus Mts.) appeared similar in cytochrome $b$ sequence to topotypes of $M$. irani Thomas 1921 and was considered to be a divergent lineage of this species (Kryštufek et al., 2009). Because of genetic and morphological differences between voles from Balkusan and Shiraz, which is the type locality of $M$. irani, the former were described as a new subspecies M. i. karamani Kryštufek, Vohralík, Zima, Koubínova \& Bužan, 2010 (Kryštufek et al., 2010). Karyotype of $M$. irani is not known with certainty (Zima et al., 2013). Diploid number $2 \mathrm{n}=62$ was reported from Shiraz and ascribed to M. irani (Golenishchev et al., 2002), however this may belong as well to $M$. socialis, which is known to occur in this part of Iran (Kryštufek \& Kefelio lu, 2001). Another $2 n=60$ chromosomal form from Central Anatoly (Kefelio lu \& Kryštufek, 1999) was described as a new species M. anatolicus Kryštufek \& Kefelio lu, 2001 (Kryštufek \& Kefelio lu, 2001b). Recently M. i. karamani was found also in northern Lebanon. The identification was based on a partial sequence of cytochrome $b$ gene but the material was not karyotyped (Kryštufek et al., 2013). In conference proceedings Golenishchev and Abramson (2011) report results on molecular data suggesting that Schidlovsky's vole and M. irani karamani may belong to the same taxon. The similar idea was advocated by Zorenko (2013) on the basis of chromosomal similarity between the two forms.

The application of molecular markers played a crucial role in stabilizing the taxonomy of social voles (Kryštufek et al., 2009, 2012), however, the mitochondrial sequence of $M$. schidlovskii remained unknown. This species was believed to be morphologically well defined among social voles by the excessive length of proximal stalk of baculum (Argyropulo, 1933).

The purpose of this study is to define the taxonomic scope of $M$. schidlovskii from Armenia using partial sequence of cytochrome $b$ gene. Next we compared $M$. schidlovskii with a chromosomal form of M. irani karamani $(2 \mathrm{n}=60)$.

\section{Material and Methods}

We studied cytochrome $b$ (cyt $b$ ) in a specimen of $M$. schidlovskii from Talin District in Armenia which is 40 $\mathrm{km}$ away from the terra typica of the species. Taxonomic identity of voles from Talin was confirmed in kariological analyses and hybridization trials (Golenishchev et al., 2002). DNA was extracted from dry museum skin using a QIAamp DNA Mini kit (Qiagen). The extracted DNA was badly degraded, which restricted our analysis to a 409 bp cytb fragment. The amplification followed protocol in Kryštufek et al. (2013). GenBank accession number for the new sequence of Microtus schidlovskii is KJ739801.

For the phylogenetic analysis, further 36 haplotypes belonging to seven species were downloaded from GenBank (Jaarola et al., 2004; Kryštufek et al., 2009, 2012, 2013): M. hartingi Barret-Hamilton, 1903 from Macedonia (Accession No. FJ767744), Greece (AY513804), and Turkey (FJ767745-7, FJ767751-2); M. guentheri Danford \& Alston, 1880 from Syria (FJ767743, AY 513805), Israel (AY513806) and Lebanon (KC953620-1); M. dogramacii Kefelio lu \& Kryštufek, 1999 from Turkey (AY513793-5); M. anatolicus Kefelio lu, 2001 from Turkey (FJ767740-2); M. irani from Turkey (FJ767748-50), Lebanon (KC953617-9) and Iran (FJ767739); M. paradoxus Ognev et Heptner, 1928 from Turkmenistan (KC953622-4); and M. socialis from Georgia (AY513829-30), Ukraine (KC953625-6), Russia (KC953627) and Iran (AY513831).

Nucleotide, amino acid composition and genetic distances were analyzed assuming a Kimura 2 parameter (K2P) sequence evolution with $10^{4}$ bootstraps in the MEGA v. 4 program (Tamura et al., 2011). The most appropriate models of DNA substitution for the data were identified using MRMODELTEST 2.3 (Nylander, 2004). Both the Akaike Information Criterion (AIC) and the hierarchical Likelihood Ratio Test (hLRT) were used. Phylogenetic analysis was conducted with the Bayesian inference (BI), using the program MRBAYES 3.1.2 (Huelsenbeck \& Ronquist, 2001; Ronquist \& Huelsenbeck, 2003), and Maximum Likelihood (ML) as implemented in the program PhyML 2.4.5 (Guindon \& Gascuel, 2003; Anisimova \& Gascuel, 2006).

The phylogenetic inferences were performed with a general time-reversible model $(\mathrm{GTR}+\mathrm{G}+\mathrm{I})(\mathrm{G}=0.5804$ and $\mathrm{I}=0.5479$ ). Four Monte Carlo Markov chains were run simultaneously for $6.5 \times 10^{6}$ generations, with the resulting trees sampled every 500 generations. Bayesian posterior probabilities (BPP) were used to assess branch support of the BI tree. Convergence for posterior probabilities was checked by examining the generation plot visualized with TRACER v1.4 (Rambaud \& Drummond, 2007).

The GTR $+\mathrm{G}$ model was used for ML analysis. Branch support (BP) in the ML tree was estimated by $10^{3}$ bootstrap replicates. The topologies resulting from these two methods were compared using a ShimodairaHasegawa test (Shimodaira \& Hasegawa, 1999) imple- 


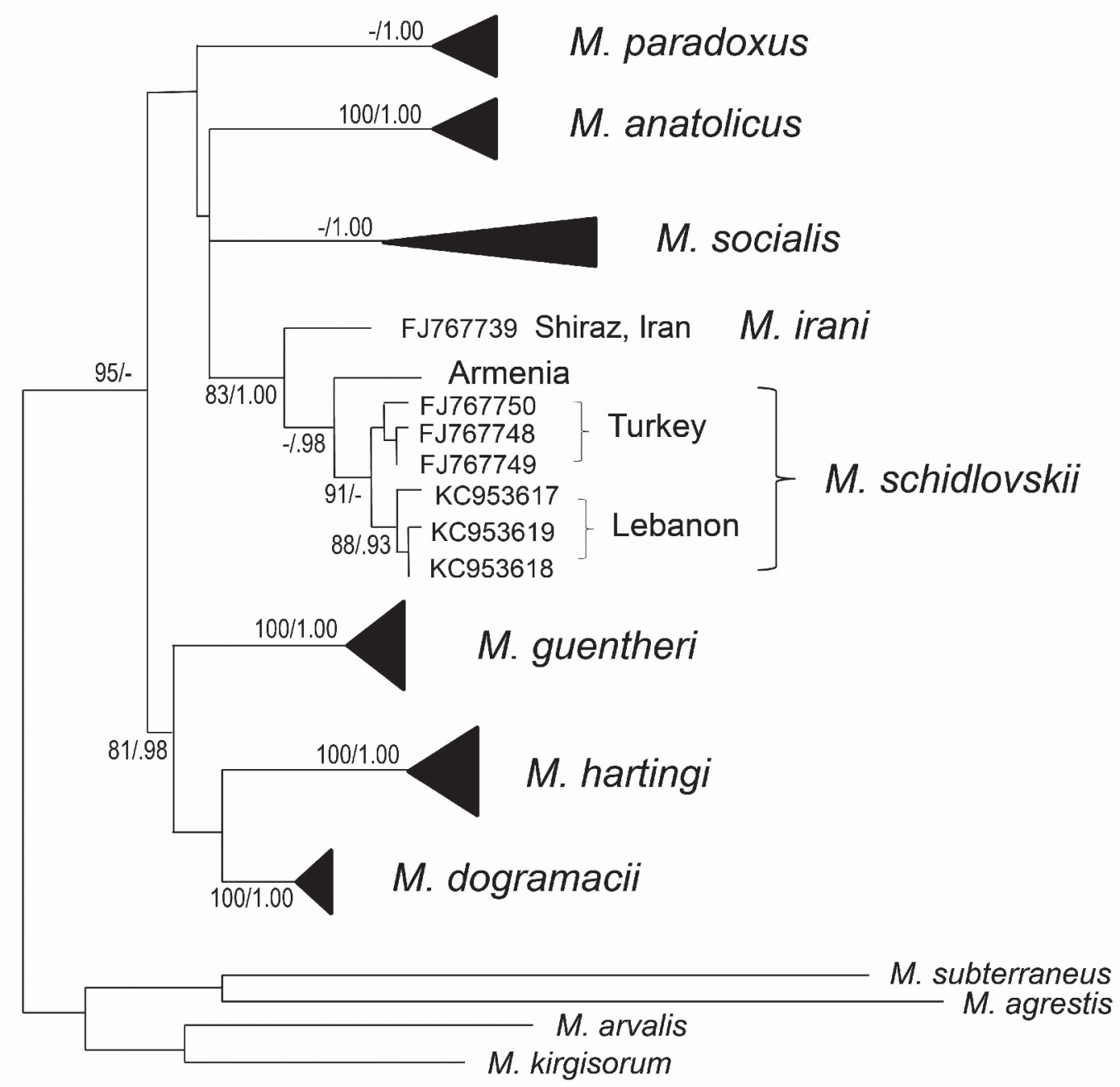

Figure 1. Maximum likelihood tree reconstructed from a 409 bp cytochrome $b$ sequences of social voles and rooted with Microtus agrestis, M. subterraneus, M. kirgisorum, and M. arvalis. The numbers on the branches correspond to bootstrap supports $(\mathrm{BP}>80 \%)$ and posterior probability values (BPP $>0.90)$. The triangles represent species of social voles which are based entirely on published haplotypes.

mented in PAUP* 4.010b (Swofford, 2002) with $10^{3}$ bootstrap replicates. We considered BPP $>0.95$ as "good", and BPP $=0.90-0.95$ as "moderate" support, in line with other authors. For branch support in the ML tree we accepted BP $>90 \%$ as "good" support, and BP $=80-90 \%$ as "moderate" support.

Trees were rooted with four Microtus species (Jaarola et al., 2004): M. arvalis Pallas, 1779 (AY220766), M. subterraneus Selys-Longchamps, 1836 (AJ717745), M. kirgisorum Ognev 1950 (AY513809), and M. agrestis Linnaeus, 1761 (AY167213).

\section{Results}

The trees obtained with the two probabilistic methods (ML and BI) present an inconsistency at a deeper node but yielded congruent results at terminal nodes. Therefore, the basal division into two major lineages (the socialis and the guentheri lineage sensu Kryštufek et al., 2012) was supported only in the ML tree (BP = 95\%), while the BI phylogenetic reconstruction placed $M$. paradoxus into well supported $(\mathrm{BPP}=1.00)$ sister position against all other social voles. Because the Shimodaira-Hasegawa test did not reveal significant differences between these trees $(\mathrm{P}=0.33)$ only the $\mathrm{ML}$ tree is shown (Figure 1). In line with published results (Kryštufek et al., 2012) seven major groups emerged which matched species recognized in earlier studies: $M$. paradoxus, M. anatolicus, $M$. socialis, M. irani, $M$. guentheri, $M$. hartingi, and $M$. dogramacii. New sequence of $M$. schidlovskii clustered with reference samples of $M$. irani, specifically as a sister group to $M$. irani karamani from Turkey and Lebanon. Therefore, M. irani within its current scope (Kryštufek et al., 2009) is paraphyletic with respect to M. schidlovskii. The monophyly of the irani-schidlovskii lineage was 


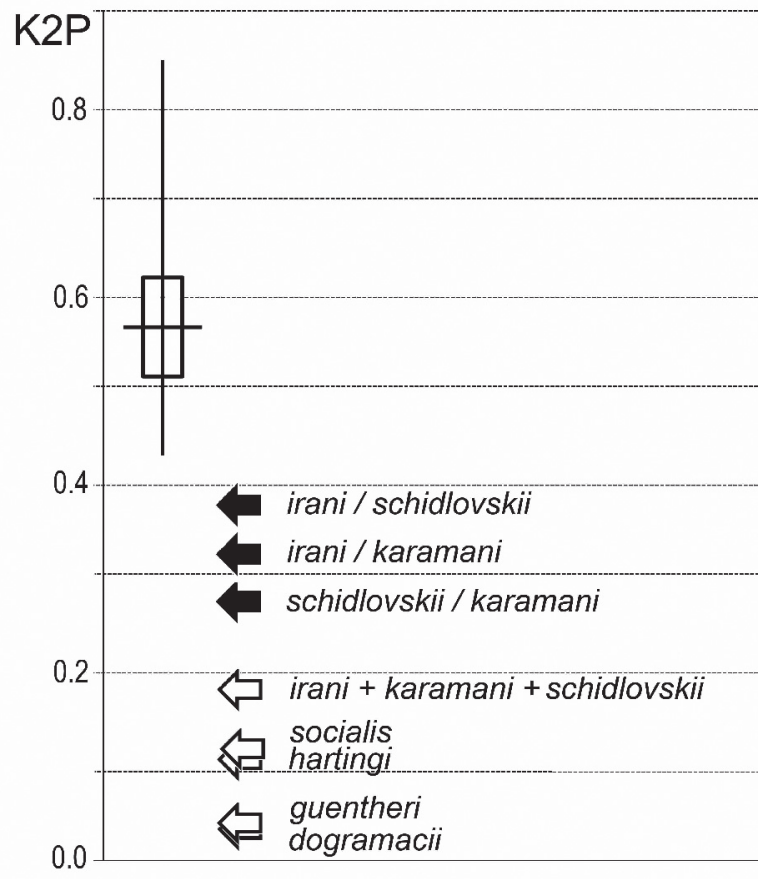

Figure 2. Box and whiskers plot of mean K2P genetic distances between the seven major lineages of social voles shown in Fig. 1. Bold line represents total range, boxes are central quartiles and horizontal line is median value. Black arrows point on distances between major sublineages of the irani-schidlovskii-karamani group. White arrows show within-species divergences. This distance was zero in M. paradoxus and $M$. anatolicus (not shown).

not supported due to unresolved polytomy in the socialis-group of species. On the other hand, all branches within this lineage benefited good support. M. irani from the type locality (Shiraz, Iran) hold strongly supported $(\mathrm{BP}=83 \%, \mathrm{BPP}=1.00)$ basal position in the group.

Mean K2P genetic distances between the major lineages were from 0.043 (between $M$. socialis and $M$. dogramacii) and 0.085 (between $M$. hartingi and $M$. anatolicus), and within group distances (excluding irani-schidlovskii-karamani group) were 0.017 (in M. socialis) and lower. Genetic distances between the three major monophiletic lineages of the irani-schidlovskiikaramani group were between the K2P distances separating major lineages (i.e. species) and distances within these groups (Figure 2). Mean K2P distance was the highest (0.038) between the irani and the schidlovskii lineages and the lowest $(0.028)$ between the schidlovskii and the karamani lineages; the distance separating the irani and karamani lineages was intermediate (0.032). This pattern may suggest a stepping stone expansion of the lineage, but more evidence is required for firm conclusions. In any case, the irani-schidlovskiikaramani group is genetically more variable than any other species group of social voles.

\section{Discussion}

Our analysis of a 409 bp fragment of cytb gene placed the sequence of $M$. schidlovskii from Armenia inside the $M$. irani cluster, more specifically as a sister group of $M$. irani karamani. Such a result is not sursprising considering that both taxa share identical diploid number of chromosomes. Evidently, karamani is conspecific with schidlovskii In accordance with the Principle of Priority as stipulated in the Article 23 of the International Code for Zoological Nomenclature (1999), schidlovskii is the senior name for the species and karamani is its junior synonym. There are morphological differences between schidlovskii and karamani, particularly so in the shape of baculum, in addition to a relatively large K2P genetic divergence, which suggest significant intraspecific structuring and the existance of well differentiated subspecies. This, however, is task for further research. For the time being we can claim with confidence, that the range of $M$. schidlovskii extends from the Armenian highlands in the east, to the Lebanese mountains in the west (Figure 3).

More puzzling are taxonomic relationships between the schidlovskii-karamani cluster and irani from Shiraz. Genetic distances among the three major monophyletic lineages of the irani-schidlovskii-karamani group in our study were between the K2P divergences which separate species of social voles and the distances within them. Therefore, based on molecular markers, $M$. irani and M. schidlovskii can be classified either as two deeply divergent infraspecific lineages or as two weakly defined species. Morphological differences between the type series of $M$. irani and $M$. schidlovskii-karamani are obvious (Kryštufek \& Kefelio lu, 2001b, Kryštufek et al., 2010). Karyotype of $M$. irani, on the other hand, is not known with certaintainty (Zima et al., 2013). Clearly, we need to gain more information in order to stabilize species taxonomy in Sumeriomys.

Though karyological data do not allow one to directly reconstruct phylogeny, the trend of reduction of number of chromosomes from high 64 and 62 to low 46 is clear. The first pair of autosomes in M. schidlovskii is large (Akhverdyan et al., 1991; Golenischev et al., 2002), similarly as in M. socialis and M. paradoxus. Emergence of taxa with diploid number 54 (M. hartingi and $M$. guentheri) possibly resulted from three simple translocations. The largest pair of autosomes in these voles consists of elements which are homologous to autosomes in 62-chromosomal voles (Golenischev et al., 2002b). Distribution of heterochromatin blocks in $M$. hartingi and $M$. socialis suggests that differences between their karyotypes are due to centromeric transformations.

Two voles with 60 chromosomes, both from the socialis group (M. schidlovskii and M. anatolicus) were found in different localities in the Armenian uplands and in Anatolia. Their karyotypes, which differ in a single translocation, were achieved independently in each species from a hypothetical ancestral karyotype by 


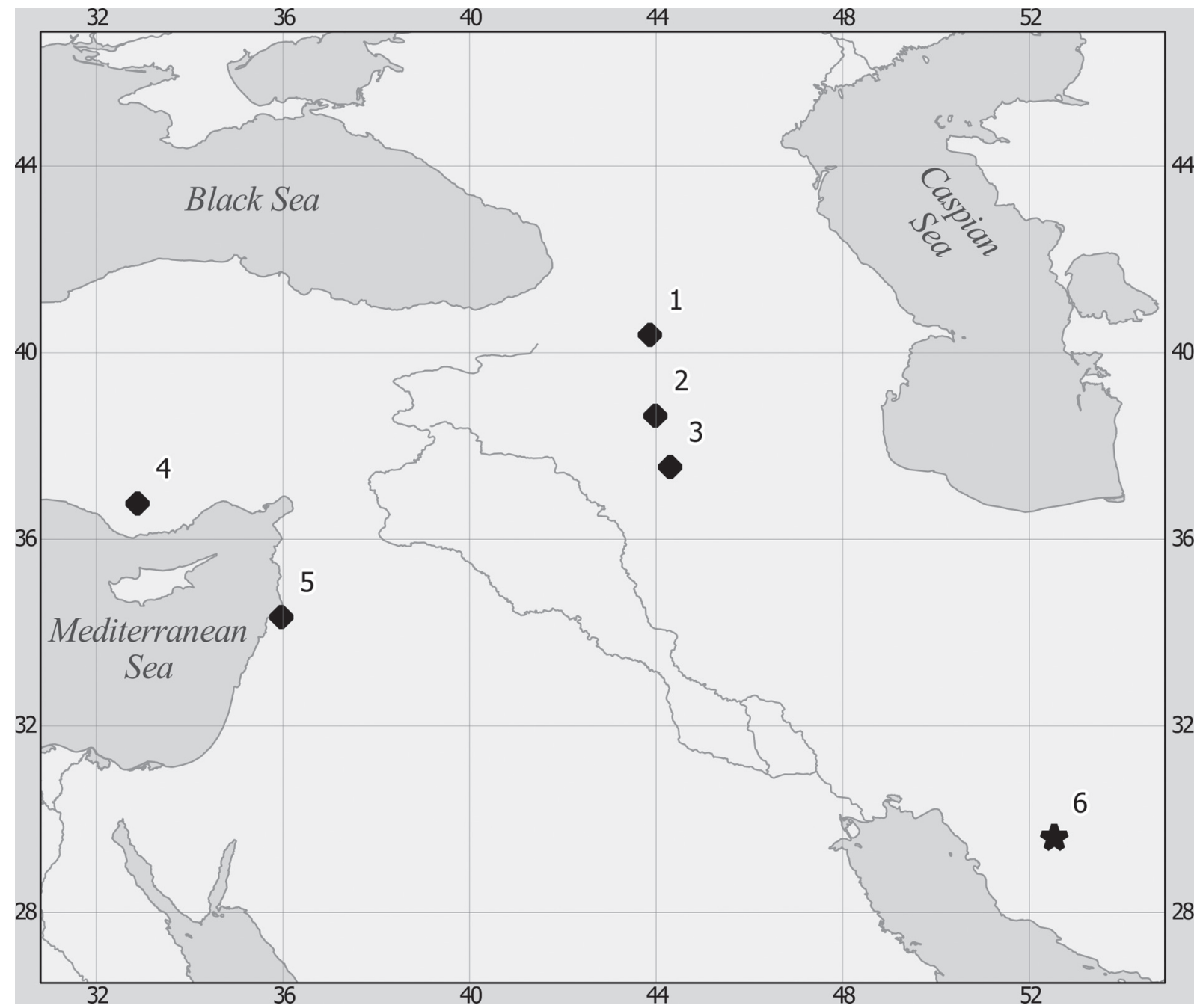

Figure 3. A map of distribution of samples of Microtus irani-schidlovskii-karamani group used in this study. M. schidlovskii: 1 - Armenia, Talin, 2 - Turkey, Yüksekova*, 3 - Özalp*, 4 - Balkusan, 5 - Lebanon; 6 - M. iran: Iran, Shiraz. * species identification is based on chromosomal evidence (Yi it et al., 2006).

a simple centromeric-telomeric tandem fusion of two acrocentric autosomes.

The distribution range of $M$. schidlovskii in western Armenia (Nalbandsky and Leninakan basins), northern spurs of Ararat, the Pambaksky ridge) is mountain isolate, probably from the Quaternary Period. According to a number of authors (Shidlovsky, 1941; Vereschagin, 1942) isolation was connected with lifting of the Armenian uplands. M. schidlovskii is allopathric to M. socialis (subspecies binominatus) which occupies eastern and southeastern parts of Armenia. The two species are segregate along the elevational gradient: $M$. schidlovskii penetrates into higher elevations (up to 1400-1700 m) while $M$. s. binominatus does not live above $600 \mathrm{~m}$ above sea level.

Our study again restricted the geographic scope of M. irani to its type locality in the Zagros Mts (Iran). It is puzzling to guess whether the range is genuinely so small or we are simply ignorant of its real extent for a shortage of reliable data. Environmental heterogeneity in the area is outstanding and this effect was further exacerbated in the past by geological and climatic dynamics. Mountains, normally detaining streams of damp air masses from the Arabian and Mediterranean seas, periodically turned dry which desiccate the entire Iranian Plateau and formed extensive saline deserts and semi-deserts. Areas of excessively arid habitat fragmented previously contiguous populations of voles, interrupted genes flow between these fragments and promoted speciation in allopatry. We may presume that populations went extinct in great number of fragments when conditions for mesophilic taxa further deteriorated. Small range of $M$. irani near Shiraz is possibly just one of originally many fragments which for some reason escaped fate of extinction. 


\section{References}

Abramson N.I., Lissovsky A.A. 2012. Subfamily Arvicolinae // Pavlinov I.Ya. \& Lissovsky A.A. (eds). The Mammals of Russia: A taxonomic and Geographic Reference (Archive of the Zoological Museum of MSU. Vol.52). Moscow: KMK Scientific Press. P.220-276.

Akhverdyan M.R., Vorontsov N.N., Lyapunova E.A. 1991a. [On the species independence of the plateau vole Microtus schidlovskii (Rodentia, Cricetidae) from the Western Armenia] // Biologicheskii Zhurnal Armenii. Vol.4. No.44. P.260-265. [In Russian].

Akhverdyan M.R., Vorontsov N.N., Lyapunova E.A. 1991b. [The plateau vole Microtus schidlovskii (Rodentia, Cricetidae) is an independent species from Armenia] // Biologicheskii Zhurnal Armenii. Vol.4. No.44. P.266-271. [in Russian].

Anisimova M., Gascuel O. 2006. Approximate likelihood ratio test for branches: a fast, accurate and powerful alternative // Systematic Biology. Vol.55. P.539-552.

Ayrumyan K.A., Akhverdyan M.R., Vorontsov N.N., Ivanitskii C.B. 1986. On systematic position of the vole Microtus socialis schidlovskii Argyropulo, 1933 // IV Congress of Theriological Society. Vol.1. Moscow: Russian Academy of Sciences. P.42-44. [In Russian].

Argyropulo A.I. 1933. Ueber zwei neue paläarktische Wühlmäuse // Zeitschrift Säugetierkunde. Vol.8. No.3. P.180183.

Golenishchev F.N., Sablina O.V., Borodin P.M., Gerasimov S. 2002a. Taxonomy of voles of the subgenus Sumeriomys Argyropulo, 1993 (Rodentia, Arvicolinae, Microtus) // Russian Journal of Theriology. Vol.1. No.1. P.43-55.

Golenishchev F.N., Malikov V.G., Nazari F., Vaziri A.Sh., Sablina O.V., Polyakov A.V. 2002b. New species of voles of "guentheri" group (Rodentia, Arvicolinae, $\mathrm{Mi}$ crotus) from Iran // Russian Journal of Theriology. Vol.1. No.2. P.117-123.

Golenishchev F.N., Abramson N.I. 2011. [New data on phylogeography of voles' subgenus Sumeriomys (Arvicolinae, Rodentia)] // Proceedings of International Conference "Mammals of Russia and Adjacent Territories". IX Congress of Theriological Society, Russian Academy of Sciences. Moscow: KMK Sci Press. P.117.

Gromov I.M., Erbajeva M.A. 1995. The mammals of Russia and adjacent territories. Lagomorphs and rodents. St.Petersburg: Russian Academy of Sciences, Zoological institute. 520 p. [in Russian].

Guindon S., Gascuel O. 2003. A simple, fast, and accurate algorithm to estimate phylogenies by maximum likelihood // Systematic Biology. Vol.52. P.696-704.

Huelsenbeck J.P., Ronquist F. 2001. MrBayes: Bayesian inference of phylogeny // Bioinformatics. Vol.17. P.754-755.

International Code for Zoological Nomenclature (Fourth edition). 1999. London: The International Trust for Zoological Nomenclature. $306 \mathrm{p}$.

Jaarola M., Martínková N., Gündüz Ý., Brunhoff C., Zima J., Nadachowski A., Amori G., Bulatova N.S., Chondropoulos B., Fraguedakis-Tsolis S., González-Esteban J., López-Fuster M.J., Kandaurov A.S., Kefelio lu H., Mathias M.L., Villatem I., Searle J.B. 2004. Molecular phylogeny of the specious vole genus Microtus (Arvicolinae, Rodentia) inferred from mitochondrial DNA sequences // Molecular Phylogenetics and Evolution. Vol.33. P.647-663.

Yi it N., Gharkheloo M.M., Çolak E., Özkurt ., Bulut ., Kank 1 ç T., Çolak R. 2006. The karyotypes of some rodent species (Mammalia: Rodentia) from eastern Turkey and northern Iran with a new record Microtus schidlovskii Argyropulo, 1933, from eastern Turkey // Turkish Journal of Zoology. Vol.30. P.459-464.

Kryštufek B., Kefelio lu H. 2001a. The social vole Microtus socialis in the Near East // Mammal Review. Vol.31. P.229-237.

Kryštufek B., Kefelio lu H. 2001b. Redescription of Microtus irani, the species limits and a new social vole from Turkey // Bonn zoological Bulletin. Vol.50. P.1-14.

Kryštufek B., Vohralik V., Zareie R., Õzkan B. 2009. Mithochondrial cytochrom $b$ sequences into the speciation of social voles in southwest Asia // Biological Journal of the Linnean Society. Vol.98. P.121-128.

Kryštufek B., Vohralik V., Zima J., Koubinová D., Bužan E. 2010. A new subspecies of the Iranian vole, Microtus irani, 1921, from Turkey // Zoology in the Middle East. Vol.50. P.11-20.

Kryštufek B., Abi-Said M., Hladnik M. 2013. The Iranian vole Microtus irani occurs in Lebanon (Mammalia: Rodentia) // Zoology in the Middle East. Vol.59. No.2. P.101-106.

Makaryan S.P., Dadikyan K.M., Papanyan S.B. 1991. [Morphological features of voles' hybrids (female Microtus schidlovskii Argyropule $1933 \times$ male Microtus socialis binominatus Ellerm, 1941)] // Biologicheskii Zhurnal Armenii. Vol.44. No.3-4. P.175-186. [In Russian].

Màrtinkovà N., Moravec J. 2012. Multilocus phylogeny of arvicoline voles (Arvicolini, Rodentia) shows small tree terrace size // Folia Zoologica. Vol.61. P.254-267.

Nylander J.A.A. 2004. Mrmodeltest, Version 2.2. Uppsala.

Rambaut A., Drummond A.J. 2007. Tracer v1.4. Available from http://beast.bio.ed.ac.uk/Tracer.

Ronquist F., Huelsenbeck J. P. 2003. MRBAYES 3: Bayesian phylogenetic inference under mixed models // Bioinformatics. Vol.19. P.1572-1574.

Shidlovsky M.V. 1941. [A guide in rodents of Georgia and adjacent territories]. Tbilisi: Izdatel'stvo AN SSR. 52 p. [in Russian].

Swofford D.L. 2002. PAUP*. Phylogenetic analysis using parsimony (*and other methods), Version 4.0b10. Sunderland (MA): Sinauer.

Tamura K., Peterson D., Peterson N., Stecher G., Nei M., Kumar S. 2011. MEGA5: Molecular Evolutionary Genetics Analysis using Maximum Likelihood, Evolutionary Distance, and Maximum Parsimony methods // Molecular Biology and Evolution. No.28. P.2731-2739.

Vereschagin N.K. 1942. [The remains of mammals from the bottom Quaternary Period deposits in Taman Peninsula] // Trudy Zoologicheskogo instituta. Vol.22. P.9-74 [in Russian].

Zakharyan Ch.A. 1958. [A question of the vole (Microtus guentheri schidlovskii Arg.) systematics] // Doklady Akademii Nauk Armyanskoy SSR. Vol.26. No.2. P.125128. [in Russian].

Zima J., Arslan A., Benda P., Macholàn M., Kryštufek B. 2013. Chromosomal variation in social voles: a Robertsonian fusion in Günter's vole // Acta teriologica. Vol.58. P. $255-265$.

Zorenko T. 2013. [Social voles of the subgenus Sumeriomys: systematics, biology and behaviour]. Saarbrücken: Palmariun Academic Publishing. 541 p. [in Russian].

Zorenko T.A., Golenishchev F.N., Skinderskaya I.A. 1997. [Peculiarities of the behaviour in social voles of the subgenus Sumeriomys (Arvicolinae, Microtus) in hybridization] // Baltic Journal of Laboratory Animal Science. Vol.7. No.2. P.77-102 [in Russian]. 